\title{
Nosocomial Methicillin-Resistant Staphylococcus aureus (MRSA) PNEUMONIA: LinEZOLID OR VANCOMYCIN? - COMPARISON OF Pharmacology and Clinical EfFicacy
}

\author{
Mathias W. Pletz, Olaf Burkhardt and Tobias Welte \\ Department of Pulmonary Medicine, Hannover Medical School, Hannover, Germany
}

\begin{abstract}
The incidence of nosocomial pneumonia involving methicillin-resistant Staphylococcus aureus strains (MRSA) is on the rise worldwide. For years, vancomycin has been used as the drug of choice in the treatment of MRSA infections and was recommended as such by clinical guidelines. There is growing evidence that vancomycin, despite low resistance rates is a suboptimal therapeutic option in critically ill patients, particularly in patients with pneumonia. Disadvantages of vancomycin are i) slow bactericide action, ii) poor penetration into pulmonary tissue, iii) the globally slowly increasing vancomycin MICs ("creep") that result in increased clinical failure despite being susceptible according to defined break points and iv) nephrotoxicity. In contrast to other novel antibiotics with MRSA activity, Linezolid is currently approved for the treatment of nosocomial pneumonia in the USA and Europe. Several studies have compared vancomycin with linezolid for nosocomial pneumonia with conflicting results. This review compares both substances regarding pharmacodynamics, resistance, safety and clinical efficacy and discusses preliminary data of the ZEPHyR study. This study compared linezolid versus vancomycin in patients with proven MRSA pneumonia and was the largest trial ever conducted in this population.
\end{abstract}

\section{Nosocomial Pneumonia - Definitions, EPIDEMIOLOGY AND PATHOGENS}

Pneumonia is defined as being nosocomial or hospitalacquired (HAP) if it becomes apparent $>48 \mathrm{~h}$ after admission to the hospital [1]. Pneumonia in ventilated patients is defined as ventilator- associated pneumonia (VAP) and considered as a subset of HAP. The risk of developing pneumonia is particularly high in patients requiring mechanical ventilation. In intensive care patients, pneumonia is the most common hospital-acquired infection. According to data of the European point-prevalence study EPIC, nosocomial pneumonia accounts for $47 \%$ of all ICU-acquired infections [2].

During the past two decades, Gram-positive bacteria (mostly staphylococci and enterococci) have been becoming increasingly prevalent in the spectrum of nosocomial pathogens besides Gram-negative bacteria. Among Gram-positives, enterococci are not con- sidered to be a relevant pathogen in pneumonia but rather colonizers [3]. This increase in Gram-positive bacteria is related to demographic changes as well as to an increase in the number of high-risk patients and intensive care measures. Extensive use of broad-spectrum antibiotics with predominantly Gram-negative coverage and the emergence of multi-drug resistant staphylococci and enterococci in the community setting further contribute to this trend [2].

According to the data of the KISS study performed in Germany, Gram-positive pathogens cause a major fraction of nosocomial pneumonias, Staphylococcus aureus being the most important pathogen in ventilator-associated pneumonia, followed by Pseudomonas aeruginosa, Klebsiella pneumoniae and Escherichia coli [4]. Of note, in that large study $(n=16,351)$ there was no difference in the rank of pathogens between early onset HAP (up to day 4 after hospitalization) and late onset VAP. Predictabilities of the occurrence of pathogens were similar and independent on pre-defined time frames for "early" and "late" onset.

\section{The Clinical Problem}

Primarily due to issues in definition, the exact attributive mortality of HAP remains a matter of debate. However, it has been confirmed by large observational studies that pneumonia is the major cause of sepsis [5, 6]. Sepsis can progress to severe sepsis and septic shock, which is associated in a drastic rise in mortality [7]. Thus, early and appropriate treatment of infection should interrupt this progression and improve patient outcome. Indeed, clinical studies have univocally shown for both, sepsis and HAP, that i) inadequate (i.e. insufficient level of agent at the site of infection) [8], ii) inappropriate (i.e. not covering the right pathogen or pathogen resistant to agent) [9] or iii) delayed antimicrobial therapy $[10,11]$ is associated with increased pneumonia mortality as well as increased length of hospital stay and costs [12].

A recent study by Kumar et al. investigating 5,715 patients with septic shock (leading focus pneumonia) in three countries found that Staphylococcus aureus was the leading individual bacterial pathogen accounting for $20 \%$ of all cases of inappropriate antimicrobial treatment, which was associated with dramatic decrease in survival [13]. Staphylococcus aureus was the only 
pathogen that correlated with mortality in a multiple logistic regression analysis carried out in a large retrospective cohort study of inpatients with culture-positive pneumonia in the USA [14]. MRSA is growing in prevalence and is now endemic in many healthcare facilities and communities [15]. In 2003, >60\% of Staphylococcus aureus isolates from US-ICUs were methicillin-resistant [16]. In Europe, there is a North to South trend in the proportion of S. aureus that is methicillin- resistant, ranging from $0 \%$ in northern European countries to $>50 \%$ in more southern countries (European Antimicrobial Resistance Surveillance System. EARSS Annual Report 2007. Bilthoven, The Netherlands: EARSS; 2008. http:/ / www.rivm.nl/earss/Images/EARSS\%202007 FINAL tcm61-55933.pdf [accessed 17 March 2010]. Some strains of MRSA, particularly those of community origin [community-acquired MRSA (CA-MRSA)], produce the Panton-Valentine leukocidin (PVL) toxin, which is associated with necrotizing infections, often in previously healthy individuals [17]. PVL-producing strains may become of increasing importance if CAMRSA strains continue to invade the hospital setting but they will not be discussed further in this article in order to maintain a focus on nosocomial pneumonia in which PVL-producing strains are much less prevalent.

\section{VANCOMYCIN}

Background: Vancomycin is a glycopeptide antibiotic that disrupts cell wall synthesis in Gram-positive bacteria by inhibiting peptidoglycan biosynthesis. An AUC/MIC ratio of $\geq 400$ has been advocated as a target to achieve clinical effectiveness with vancomycin. Animal studies and limited human data appear to demonstrate that vancomycin is not concentration dependent and that the AUC/MIC is a predictive pharmacokinetic parameter for vancomycin for review see [18].

Pros: Vancomycin is currently (still) the treatment of choice in MRSA pneumonia. Therefore it served as comparator in most phase III MRSA pneumonia trials. Complete resistance to vancomycin is conferred by the vanA determinant and has yet been detected only in individual patients [19].

Cons: However, there are some clinically important disadvantages regarding the use of vancomycin for the treatment of pneumonia:

i) MICs have been observed to be increasing over time (MIC creep) [20, 21]. Such isolates are still considered to be susceptible per definition since the MIC is below defined breakpoints. Nonetheless, relationship between increased MIC and treatment success or failure in serious Staphylococcus aureus infections has recently been established. Failure rates exceeding 60\% for Stapbylococcus aureus displaying a vancomycin MIC value of $4 \mathrm{mg} / \mathrm{L}$ prompted recommendations in 2006 from the Clinical and Laboratory Standards Institute to lower the breakpoint for susceptibility from 4 to $2 \mathrm{mg} / \mathrm{L}$ and in 2008 from the US Food and Drug Administration. Meanwhile, a number of studies have established a relationship between vancomycin treat- ment failures and infections in patients with methicillin-resistant Stapbylococcus aureus displaying an MIC of $2 \mathrm{mg} / 1$ (for review see $[22,23]$. This trend has urged the IDSA to issue "Vancomycin Therapeutic Guidelines" that recommend to aim for trough serum vancomycin concentrations of $15-20 \mathrm{mg} /$ and to maintain trough serum vancomycin concentrations always $>10 \mathrm{mg} / \mathrm{L}$ to avoid the development of resistance. Further, alternative treatment is recommended for isolates with $\mathrm{MIC}>2 \mathrm{mg} / \mathrm{l}$, because a targeted AUC/MIC of 400 is not achievable with conventional dosing [22].

ii) Vancomycin penetrates poorly into the lung, only $<12 \%$ of plasma levels [24] are detected in pulmonary epithelial lining fluid at therapeutic doses which is associated with pneumonia treatment failure despite the in vitro susceptibility of the bacterial isolates [25-27].

iii) Vancomycin is considered slowly bactericidal according to in vitro killing curves [28].

iv) Vancomycin is associated with nephrotoxicity and ototoxicity, although the frequency of these adverse reactions was higher in early reports and is attributed to the low purity of early formulations [29]. Nephrotoxicity due to vancomycin is of great concern due to the contribution of acute kidney injury to poor clinical outcome in critically ill patients in the ICU, a population particularly vulnerable to MRSA infection [30-33]. In addition, the recently recommended increased through levels are associated with increased nephrotoxicity.

The disadvantages of vancomycin can in part be compensated by adding a second antibiotic with MRSA activity and good tissue penetration, e.g. rifampin. In vitro studies have suggested a synergism between vancomycin and rifampin [34, 35]. Combination of vancomycin with rifampin has been used since the 1970s [36] and has been advocated by some opinion leaders despite the lack of data from randomized controlled trials (RCT). Recently, the first RCT from Korea with 83 enrolled cases demonstrated superiority of vancomycin/rifampin versus vancomycin alone in patients with MRSA pneumonia: the clinical cure rate in the modified intention-to-treat population was 53.7 $\%$ (22 of 41 ) in the vancomycin plus rifampin group, and $31.0 \%$ (13 of 42$)$ in the vancomycin-only group $(p=.047)[37,38]$. However, it has to be considered that resistance to rifampin evolves easily and broad use of this combination may result in a fast increase of resistance to rifampin. Another drawback of rifampin is drug interactions that limit its use in critically ill patients and patients under immunosuppressive therapy.

\section{LINEZOLID}

Background. Linezolid is the first oxazolidinone available for clinical use [39]. It inhibits bacterial protein synthesis via a new mechanism. While macrolides, tetracyclines, and aminoglycosides inhibit the elongation of already initiated peptide chains, linezolid prevents the initiation of protein synthesis by blocking the assembly of a functional initiation complex. This mechanism of action precludes cross-resistance with other protein synthesis inhibitors (for review see [40]. In vitro studies have shown that the antibacterial activi- 
ty of linezolid is concentration-dependent rather than time-dependent with AUC/MIC as the best parameter predicting the in-vivo efficacy [41, 42]. Linezolid has activity against Gram-positive pathogens, including bacteriostatic in vitro activity for staphylococci, but has limited activity against Gram-negative bacteria [43].

Pros: Linezolid is besides vancomycin currently the only of the novel drugs with MRSA-activity that is approved for the treatment of nosocomial pneumonia in the USA and Europe, including cases caused by MRSA. In the USA it represents the only alternative to vancomycin for this indication [23]. Pulmonary penetration of linezolid is good: $415 \%$ of plasma levels were recovered in epithelial lining fluid [44].

In contrast to other antibacterial drugs used in the treatment of severe Gram-positive infections (glycopeptides, lipoglycopeptides, quinupristin/dalfopristin, daptomycin, tigecycline, cephalosporins with MRSA-activity), linezolid is available for both intravenous and oral administration. The bioavailability of oral formulations approaches $100 \%$ [45], while food has no relevant effect on drug exposition. The elimination half-life is in the 4 to $5 \mathrm{~h}$ range requiring twice daily administration. Standard dosages are $600 \mathrm{mg}$ $\mathrm{q} 12 \mathrm{~h}$ for both intravenous and oral administration. There is a slight, probably not clinically relevant accumulation after oral administration [46].

Resistance was first observed in a clinical Staphylococcus aureus isolate in 2001 [47], although the LEADER surveillance program has shown that 99.55 $\%$ of isolates remained susceptible to linezolid in the USA in 2006 [48].

Cons: Thrombocytopenia is a commonly observed adverse reaction to linezolid therapy, with occurrence rates of around $30 \%$ [49-51], a rate much higher than that reported in phase 3 trials [43]. Thrombocytopenia is more common following prolonged treatment $(>14$ days) and in patients with renal insufficiency [50, 52]. The inhibition of mitochondrial protein synthesis by linezolid - studied in one case by De Vriese - can result in potentially severe clinical effects including optic/peripheral neuropathy and lactic acidosis [53]. These events are not frequently observed and are mostly reversible following termination of linezolid treatment, but there are reports of severe irreversible effects, such as permanent blindness, in patients treated only for a short time [54]. As a reversible, non-selective monoamine oxidase inhibitor, linezolid in combination with serotonergic agents has been associated with serotonin syndrome [55]. The linezolid licence recommends that treatment should be restricted to a maximum of 28 days [43].

\section{LINEZOLID VERSUS VANCOMYCIN IN PNEUMONIA - InCONCLUSIVE RESUlts OF \\ TRIALS AND META-ANALYSES LEAD TO DIFFERENT RECOMMENDATIONS BY GUIDELINES}

Two retrospective subgroup analyses of ventilated and non-ventilated patients with MRSA [56, 57] from nosocomial pneumonia clinical trials $[58,59]$ showed that linezolid-treated patients had higher survival and clinical cure rates than vancomycin-treated patients. It has been suggested that this may be due to the favourable intrapulmonary distribution of linezolid [60]. However, the viability and validity of these subset analyses has been questioned [61, 62], such that further trials are required before linezolid can be recommended to be used preferentially over vancomycin for the treatment of MRSA pneumonia. A recent trial of patients with MRSA-VAP, which was designed and powered to demonstrate "non-inferiority" of linezolid to vancomycin demonstrated numerically better values for linezolid-treated patients compared with vancomycin-treated patients with respect to microbiological eradication $(56.5 \%$ and $47.4 \%$, respectively), clinical cure $(66.7 \%$ and $52.9 \%$, respectively), survival rate (86.7 \% and $70.0 \%$, respectively) and length of hospitalization (18.8 and 20.1 days, respectively), ventilation (10.4 and 14.3 days, respectively) and ICU stay (12.2 and 16.2 days, respectively) [63]. For the small number of subjects in this study these differences were not statistically significant.

A recent meta-analysis including 9 trials comparing glycopeptides (7 vancomycin and 2 teicoplanin) with linezolid found that the linezolid versus glycopeptide analysis showed a clinical cure relative risk of 1.01 (95 $\%$ confidence interval, $0.93-1.10 ; p=.83 ; \mathrm{I}(2)=0 \%)$ and a microbiological eradication relative risk of 1.10 (95\% confidence interval, $0.98-1.22 ; \mathrm{p}=0.10$ ) [64]. In contrast, they found that the risks of thrombocytopenia (relative risk, 1.93; $95 \%$ confidence interval, 1.30-2.87; $\mathrm{p}=0.001$ ) and gastrointestinal events (relative risk, 2.02; $95 \%$ confidence interval, 1.10-3.70; $\mathrm{p}=$ 0.02 ) were higher with linezolid, but they did see no differences for renal dysfunction or all-cause mortality (relative risk, 0.95; $95 \%$ confidence interval, 0.76-1.18; $\mathrm{p}=0.63$ ). The authors therefore concluded that linezolid was not superior to vancomycin in pneumonia. However, only 3 of these studies enrolled exclusively patients with pneumonia [64].

Despite using the same trials for calculation, a second meta-analysis found also no difference in treatment success for patients pneumonia $(\mathrm{OR}=1.16,95 \%$ CI 0.85-1.57) but a trend for better eradication rates in all microbiologically assessed patients for linezolid $(\mathrm{OR}=1.33,95 \%$ CI 1.03-1.71). In contrast to Kalil et al. they found no difference in total adverse effects $(\mathrm{OR}=1.14,95 \%$ CI 0.82-1.59) but more nephrotoxicity in patients receiving vancomycin $(\mathrm{OR}=0.31,95 \%$ CI 0.13-0.74) [65].

As clinical data on linezolid in HAP/VAP are inconclusive so are the recommendations of current guidelines. The ATS/IDSA guideline on HAP/VAP does not advocate to preferred use of linezolid in patients with HAP/VAP [1]. In contrast, the German sepsis guideline recommends linezolid in proven MRSA pneumonia and expressively warns to rely on vancomycin mono-therapy in such cases [66].

\section{ZEPHYR STUDY}

In order to resolve these questions Pfizer initiated a probably final - international phase 4 study to compare linezolid to vancomycin for the treatment of 
nosocomial pneumonia proven due to MRSA. The complete results of that study have not been published yet, but preliminary results were presented at the $48^{\text {th }}$ Annual Meeting of the Infectious Diseases Society of America (IDSA) in Boston on October 23, 2010 by Jean Chastre (Abstract \#5047). The ZEPHyR (Linezolid in the treatment of subjects with nosocomial pneumonia proven to be due to methicillin-resistant Staphylococcus aureus) study was the largest ever conducted in this population. The study was designed as non-inferiority trial with nested superiority hypothesis.

Investigators from 156 centers worldwide randomized 1,225 patients, of whom 448 patients had proven MRSA nosocomial pneumonia (modified intent-totreat group); 339 patients also met key protocol criteria at the end of study (per-protocol group) and were included in the primary analysis. In the per protocol group, 125 patients treated with linezolid (68.3\%) and $140(74.5 \%)$ treated with vancomycin were ventilated at baseline. Mean vancomycin through level on day 3 was $14.1 \mathrm{mg} / 1$ (95 \% CI 2.8-50.8\%; $\mathrm{n}=140)$. Interestingly, clinical response rates in the mITT were not influenced by vancomycin through levels. Clinical success rates at the end of study were 57.6 percent (95/165) for patients treated with linezolid compared with 46.6 percent $(81 / 174)$ for patients treated with vancomycin in the per-protocol group, the primary endpoint. These results demonstrated that linezolid achieved a statistically significantly higher clinical success rate compared to vancomycin (95\% CI for the difference in response rates: $0.5 \%, 21.6 \% ; \mathrm{p}=0.042$ ). Results were consistent for the per-protocol group at end of treatment and for all MRSA pneumonia subjects (modified intent-to-treat) at end of treatment and end of study. Microbiologic success was also consistent in both the per-protocol and the modified intentto-treat groups at both end of treatment and end of study. Overall mortality was $15.7 \%$ for linezolid and $17.0 \%$ for vancomycin.

Thrombocytopenia (linezolid $1.3 \%$, vancomycin $2.2 \%$ ) and renal failure (linezolid $3.8 \%$; vancomycin $7.2 \%$ ) occurred at relatively low rates.

\section{CONCLUSION}

There is growing evidence that vancomycin, despite low resistance rates is a suboptimal therapeutic option in critically ill patients, particularly in patients with pneumonia. Disadvantages of vancomycin are i) slow bactericide action, ii) poor penetration into pulmonary tissue, iii) the globally slowly increasing vancomycin MICs ("creep") that result in increased clinical failure despite being susceptible according to defined break points and iv) nephrotoxicity. Vancomycin has been shown to be less effective than $\beta$-lactams for the treatment of MSSA infections [26, 67-69] and beta-lactams should be used when possible. In MRSA infections at least poor tissue penetration and bactericidal effect can be improved by combination with rifampin according to in vitro and animal studies and one prospective randomized controlled trial [38]. However, this approach has serious limitations such as the risk of emerging of rifampin resistance and drug interactions.
For MRSA pneumonia current treatment options are limited. Daptomycin is inactivated by surfactant [70, 71] and will not be investigated for pneumonia, tigecyclin ( \pm ceftazidim) was significantly inferior to the comparator imipenem ( \pm vancomycin) in a prospective study in patients with nosocomial pneumonia [72]. Quinupristin-dalfopristin is approved for the treatment of MRSA pneumonia in some European countries, but not in the USA [73]. The ATS/IDSA nosocomial pneumonia guidelines do not recommend quinupristin-dalfopristin for the treatment of MRSA pneumonia due to clinical cure rates being lower than vancomycin in clinical trials $[74,75]$.

In fact, linezolid is currently the only licensed and well studied alternative to vancomycin in MRSA pneumonia. Conflicting results of smaller prospective studies, meta-analysis of these studies and retrospective observations can now be replaced by the new findings of the ZEPHyR study, advocating the superiority of linezolid over vancomycin in proven MRSA pneumonia.

\section{REFERENCES}

1. Guidelines for the management of adults with hospitalacquired, ventilator-associated, and healthcare-associated pneumonia. Am J Respir Crit Care Med. 2005 Feb 15; 171(4):388-416.

2. Vincent JL, Bihari DJ, Suter PM, Bruining HA, White J, Nicolas- Chanoin $\mathrm{MH}$, et al. The prevalence of nosocomial infection in intensive care units in Europe: Results of the European Prevalence of Infection in Intensive Care (EPIC) study. Journal of the American Medical Association. 1995;274(8):639-44.

3. Grupper M, Kravtsov A, Potasman I. Enterococcal-associated lower respiratory tract infections: a case report and literature review. Infection. 2009 Feb;37(1):60-4.

4. Gastmeier P, Sohr D, Geffers C, Ruden H, Vonberg RP, Welte T. Early- and late-onset pneumonia: is this still a useful classification? Antimicrob Agents Chemother. 2009 Jul;53(7):2714-8.

5. Bloos F, Hinder F, Becker K, Sachse S, Mekontso Dessap A, Straube E, et al. A multicenter trial to compare blood culture with polymerase chain reaction in severe human sepsis. Intensive Care Med. 2010 Feb;36(2): 241-7.

6. Alberti C, Brun-Buisson C, Chevret S, Antonelli M, Goodman SV, Martin C, et al. Systemic inflammatory response and progression to severe sepsis in critically ill infected patients. Am J Respir Crit Care Med. 2005 Mar 1;171(5):461-8.

7. Valles J, Rello J, Ochagavia A, Garnacho J, Alcala MA. Community-acquired bloodstream infection in critically ill adult patients: impact of shock and inappropriate antibiotic therapy on survival. Chest. 2003 May;123(5): 1615-24.

8. Kollef MH, Sherman G, Ward S, Fraser VJ. Inadequate antimicrobial treatment of infections: A risk factor for hospital mortality among critically III patients. Chest. 1999;115(2):462-74.

9. Luna CM, Vujacich P, Niederman MS, Vay C, Gherardi C, Matera J, et al. Impact of BAL data on the therapy and outcome of ventilator-associated pneumonia. Chest. 1997;111(3):676-85.

10. Iregui M, Ward S, Sherman G, Fraser VJ, Kollef MH. Clinical importance of delays in the initiation of appropriate antibiotic treatment for ventilator-associated pneumonia. Chest. 2002;122(1):262-8. 
11. Kumar A, Haery C, Paladugu B, Symeoneides S, Taiberg L, Osman J, et al. The duration of hypotension before the initiation of antibiotic treatment is a critical determinant of survival in a murine model of Escherichia coli septic shock: association with serum lactate and inflammatory cytokine levels. J Infect Dis. 2006 Jan 15;193(2):251-8.

12. Shorr AF, Micek ST, Kollef MH. Inappropriate therapy for methicillin-resistant Staphylococcus aureus: Resource utilization and cost implications. Critical Care Medicine. 2008;36(8):2335-40.

13. Kumar A, Ellis P, Arabi Y, Roberts D, Light B, Parrillo $\mathrm{JE}$, et al. Initiation of inappropriate antimicrobial therapy results in a fivefold reduction of survival in human septic shock. Chest. 2009 Nov;136(5):1237-48.

14. Kollef MH, Shorr A, Tabak YP, Gupta V, Liu LZ, Johannes RS. Epidemiology and outcomes of health-careassociated pneumonia: Results from a large US database of culture-positive pneumonia. Chest. 2005;128(6): 3854-62.

15. Klein E, Smith DL, Laxminarayan R. Hospitalizations and deaths caused by methicillin-resistant Staphylococcus aureus, United States, 1999-2005. Emerging Infectious Diseases. 2007;13(12):1840-6.

16. Klevens RM, Edwards JR, Tenover FC, McDonald LC, Horan T, Gaynes R. Changes in the epidemiology of methicillin-resistant Staphylococcus aureus in intensive care units in US hospitals, 1992-2003. Clin Infect Dis. 2006 Feb 1;42(3):389-91.

17. Hidron AI, Low CE, Honig EG, Blumberg HM. Emergence of community-acquired meticillin-resistant Staphylococcus aureus strain USA300 as a cause of necrotising community-onset pneumonia. The Lancet Infectious Diseases. 2009;9(6):384-92.

18. Rybak M, Lomaestro B, Rotschafer JC, Moellering Jr R, Craig W, Billeter $\mathrm{M}$, et al. Therapeutic monitoring of vancomycin in adult patients: A consensus review of the American Society of Health-System Pharmacists, the Infectious Diseases Society of America, and the Society of Infectious Diseases Pharmacists. American Journal of Health-System Pharmacy. 2009;66(1):8298.

19. Chang S, Sievert DM, Hageman JC, Boulton ML, Tenover FC, Downes FP, et al. Infection with vancomycinresistant Staphylococcus aureus containing the vanA resistance gene. The New England journal of medicine. 2003 Apr 3;348(14):1342-7.

20. Steinkraus G, White R, Friedrich L. Vancomycin MIC creep in non-vancomycin-intermediate Staphylococcus aureus (VISA), vancomycin-susceptible clinical methicillin-resistant S. aureus (MRSA) blood isolates from 2001-05. The Journal of antimicrobial chemotherapy. 2007 Oct;60(4):788-94.

21. Wang G, Hindler JF, Ward KW, Bruckner DA. Increased vancomycin MICs for Staphylococcus aureus clinical isolates from a university hospital during a 5year period. Journal of clinical microbiology. 2006 Nov;44(11):3883-6.

22. Rybak MJ, Lomaestro BM, Rotschafer JC, Moellering RC, Craig WA, Billeter M, et al. Vancomycin therapeutic guidelines: a summary of consensus recommendations from the infectious diseases Society of America, the American Society of Health-System Pharmacists, and the Society of Infectious Diseases Pharmacists. Clin Infect Dis. 2009 Aug 1;49(3):325-7.

23. Welte T, Pletz MW. Antimicrobial treatment of nosocomial meticillin-resistant Staphylococcus aureus (MRSA) pneumonia: current and future options. Int J Antimicrob Agents. 2010 Nov;36(5):391-400.
24. Georges H, Leroy O, Alfandari S, Guery B, RousselDelvallez M, Dhennain C, et al. Pulmonary disposition of vancomycin in critically ill patients. Eur J Clin Microbiol Infect Dis. 1997 May;16(5):385-8.

25. Cruciani M, Gatti G, Lazzarini L, Furlan G, Broccali G, Malena $M$, et al. Penetration of vancomycin into human lung tissue. The Journal of antimicrobial chemotherapy. 1996 Nov;38(5):865-9.

26. González C, Rubio M, Romero-Vivas J, González M, Picazo JJ. Bacteremic pneumonia due to Staphylococcus aureus: a comparison of disease caused by methicillin-resistant and methicillin-susceptible organisms. Clin Infect Dis. 1999 Nov;29(5):1171-7.

27. Scheetz MH, Wunderink RG, Postelnick MJ, Noskin GA. Potential impact of vancomycin pulmonary distribution on treatment outcomes in patients with methicillin-resistant Staphylococcus aureus pneumonia. Pharmacotherapy. 2006;26(4):539-50.

28. Flandrois JP, Fardel G, Carret G. Early stages of in vitro killing curve of LY146032 and vancomycin for Staphylococcus aureus. Antimicrob Agents Chemother. 1988 Apr; 32(4):454-7.

29. Levine DP. Vancomycin: a history. Clin Infect Dis. 2006 Jan 1;42(Suppl 1):S5-12.

30. Kielstein JT, Kretschmer U, Ernst T, Hafer C, Bahr MJ, Haller $\mathrm{H}$, et al. Efficacy and cardiovascular tolerability of extended dialysis in critically ill patients: a randomized controlled study. Am J Kidney Dis. 2004 Feb;43(2):342-9.

31. Metnitz PG, Krenn CG, Steltzer H, Lang T, Ploder J, Lenz $\mathrm{K}$, et al. Effect of acute renal failure requiring renal replacement therapy on outcome in critically ill patients. Critical care medicine. 2002 Sep;30(9):2051-8.

32. Sesso R, Roque A, Vicioso B, Stella S. Prognosis of ARF in hospitalized elderly patients. Am J Kidney Dis. 2004 Sep;44(3):410-9.

33. Vinsonneau C, Camus C, Combes A, Costa de Beauregard MA, Klouche K, Boulain T, et al. Continuous venovenous haemodiafiltration versus intermittent haemodialysis for acute renal failure in patients with multipleorgan dysfunction syndrome: a multicentre randomised trial. Lancet. 2006;368(9533):379-85.

34. Palmer SM, Rybak MJ. Pharmacodynamics of once- or twice-daily levofloxacin versus vancomycin, with or without rifampin, against Staphylococcus aureus in an in vitro model with infected platelet-fibrin clots. Antimicrob Agents Chemother. 1996 Mar;40(3):7015.

35. Varaldo PE, Debbia E, Schito GC. In vitro activity of teichomycin and vancomycin alone and in combination with rifampin. Antimicrob Agents Chemother. 1983 Mar;23(3): 402-6.

36. Faville RJ, Jr., Zaske DE, Kaplan EL, Crossley K, Sabath LD, Quie PG. Staphylococcus aureus endocarditis. Combined therapy with vancomycin and rifampin. JAMA. 1978 Oct 27;240(18):1963-5.

37. Jung YJ, Koh Y, Hong SB, Chung JW, Choi SH, Kim NJ, et al. Effect of vancomycin plus rifampicin in the treatment of nosocomial methicillin-resistant Staphylococcus aureus pneumonia. Critical Care Medicine. 2010;38(1): 175-80.

38. Jung YJ, Koh Y, Hong SB, Chung JW, Ho Choi S, Kim NJ, et al. Effect of vancomycin plus rifampicin in the treatment of nosocomial methicillin-resistant Staphylococcus aureus pneumonia. Crit Care Med. 2010 Jan;38(1): 175-80.

39. Marchese A, Schito GC. The oxazolidinones as a new family of antimicrobial agent. Clinical Microbiology and Infection. 2001;7(SUPPL. 4):66-74. 
40. Burkhardt O, Pletz MW, Mertgen CP, Welte T. Linezolid - the first oxazolidinone in the treatment of nosocomial MRSA pneumonia. Recent Pat Antiinfect Drug Discov. 2007 Jun;2(2):123-30.

41. Craig WA. Basic pharmacodynamics of antibacterials with clinical applications to the use of beta-lactams, glycopeptides, and linezolid. Infect Dis Clin North Am. 2003 Sep;17(3):479-501.

42. Andes D, van Ogtrop ML, Peng J, Craig WA. In vivo pharmacodynamics of a new oxazolidinone (linezolid). Antimicrob Agents Chemother. 2002 Nov;46(11):34849.

43. Zyvox [package insert]. New York, NY: Pfizer, Inc; 2008.

44. Conte Jr JE, Golden JA, Kipps J, Zurlinden E. Intrapulmonary pharmacokinetics of linezolid. Antimicrobial Agents and Chemotherapy. 2002;46(5):1475-80.

45. Stalker DJ, Jungbluth GL. Clinical Pharmacokinetics of Linezolid, a Novel Oxazolidinone Antibacterial. Clinical Pharmacokinetics. 2003;42(13):1129-40.

46. Burkhardt O, Borner K, von der Hoh N, Koppe P, Pletz MW, Nord CE, et al. Single- and multiple-dose pharmacokinetics of linezolid and co-amoxiclav in healthy human volunteers. J Antimicrob Chemother. 2002 Nov; 50(5):707-12.

47. Tsiodras S, Gold HS, Sakoulas G, Eliopoulos GM, Wennersten C, Venkataraman L, et al. Linezolid resistance in a clinical isolate of Staphylococcus aureus. Lancet. 2001 Jul 21;358(9277):207-8.

48. Jones RN, Fritsche TR, Sader HS, Ross JE. LEADER surveillance program results for 2006: an activity and spectrum analysis of linezolid using clinical isolates from the United States (50 medical centers). Diagnostic microbiology and infectious disease. 2007 Nov;59(3): $309-17$.

49. Attassi K, Hershberger E, Alam R, Zervos MJ. Thrombocytopenia associated with linezolid therapy. Clin Infect Dis. 2002 Mar 1;34(5):695-8.

50. Bishop E, Melvani S, Howden BP, Charles PG, Grayson ML. Good clinical outcomes but high rates of adverse reactions during linezolid therapy for serious infections: a proposed protocol for monitoring therapy in complex patients. Antimicrobial agents and chemotherapy. 2006 Apr;50(4):1599-602.

51. Orrick JJ, Johns T, Janelle J, Ramphal R. Thrombocytopenia secondary to linezolid administration: what is the risk? Clin Infect Dis. 2002 Aug 1;35(3):348-9.

52. Lin YH, Wu VC, Tsai IJ, Ho YL, Hwang JJ, Tsau YK, et al. High frequency of linezolid-associated thrombocytopenia among patients with renal insufficiency. International journal of antimicrobial agents. 2006 Oct;28(4): 345-51.

53. De Vriese AS, Coster RV, Smet J, Seneca S, Lovering A, Van Haute LL, et al. Linezolid-induced inhibition of mitochondrial protein synthesis. Clin Infect Dis. 2006 Apr 15;42(8):1111-7.

54. Azamfirei L, Copotoiu SM, Branzaniuc K, Szederjesi J, Copotoiu R, Berteanu C. Complete blindness after optic neuropathy induced by short-term linezolid treatment in a patient suffering from muscle dystrophy. Pharmacoepidemiology and drug safety. 2007 Apr;16(4):402-4.

55. Lawrence KR, Adra M, Gillman PK. Serotonin toxicity associated with the use of linezolid: a review of postmarketing data. Clin Infect Dis. 2006 Jun 1;42(11):157883.

56. Kollef MH, Rello J, Cammarata SK, Croos-Dabrera RV, Wunderink RG. Clinical cure and survival in Gram-positive ventilator-associated pneumonia: retrospective analysis of two double-blind studies comparing linezolid with vancomycin. Intensive Care Med. 2004 Mar;30(3): 388-94.

57. Wunderink RG, Rello J, Cammarata SK, Croos-Dabrera RV, Kollef MH. Linezolid vs vancomycin: analysis of two double-blind studies of patients with methicillin-resistant Staphylococcus aureus nosocomial pneumonia. Chest. 2003 Nov;124(5):1789-97.

58. Rubinstein E, Cammarata S, Oliphant T, Wunderink R, Group. LNPS. Linezolid (PNU-100766) versus vancomycin in the treatment of hospitalized patients with nosocomial pneumonia: a randomized, double-blind, multicenter study. Clin Infect Dis. 2001 Feb 1;32(3): 402-12.

59. Wunderink RG, Cammarata SK, Oliphant TH, Kollef $\mathrm{MH}$. Continuation of a randomized, double-blind, multicenter study of linezolid versus vancomycin in the treatment of patients with nosocomial pneumonia. Clin Ther. 2003 Mar;25(3):980-92.

60. Conte JE, Jr., Golden JA, Kipps J, Zurlinden E. Intrapulmonary pharmacokinetics of linezolid. Antimicrobial agents and chemotherapy. 2002 May;46(5):1475-80.

61. Powers JH, Lin D, Ross D. FDA evaluation of antimicrobials: subgroup analysis. Chest. 2005 Jun;127(6): 2298-9.

62. Powers JH, Ross DB, Lin D, Soreth J. Linezolid and vancomycin for methicillin-resistant Staphylococcus aureus nosocomial pneumonia: the subtleties of subgroup analyses. Chest. 2004 Jul;126(1):314-5.

63. Wunderink RG, Mendelson MH, Somero MS, Fabian TC, May AK, Bhattacharyya H, et al. Early microbiological response to linezolid vs vancomycin in ventilatorassociated pneumonia due to methicillin-resistant Staphylococcus aureus. Chest. 2008 Dec;134(6):1200-7.

64. Kalil AC, Murthy MH, Hermsen ED, Neto FK, Sun J, Rupp ME. Linezolid versus vancomycin or teicoplanin for nosocomial pneumonia: a systematic review and meta-analysis. Crit Care Med. 2010 Sep;38(9):1802-8.

65. Beibei L, Yun C, Mengli C, Nan B, Xuhong Y, Rui W. Linezolid versus vancomycin for the treatment of grampositive bacterial infections: meta-analysis of randomised controlled trials. Int J Antimicrob Agents. 2010 Jan;35(1): 3-12.

66. Reinhart K, Brunkhorst FM, Bone HG, Bardutzky J, Dempfle CE, Forst H, et al. Prevention, diagnosis, therapy and follow-up care of sepsis: 1st revision of S-2k guidelines of the German Sepsis Society (Deutsche Sepsis-Gesellschaft e.V. (DSG)) and the German Interdisciplinary Association of Intensive Care and Emergency Medicine (Deutsche Interdisziplinare Vereinigung fur Intensiv- und Notfallmedizin (DIVI)). Ger Med Sci. 2010; 8:Doc14.

67. Chang FY, Peacock JE, Jr., Musher DM, Triplett P, MacDonald BB, Mylotte JM, et al. Staphylococcus aureus bacteremia: recurrence and the impact of antibiotic treatment in a prospective multicenter study. Medicine. 2003 Sep;82(5):333-9.

68. Lodise TP, Jr., McKinnon PS, Levine DP, Rybak MJ. Impact of empirical-therapy selection on outcomes of intravenous drug users with infective endocarditis caused by methicillin-susceptible Staphylococcus aureus. Antimicrobial agents and chemotherapy. 2007 Oct;51(10):3731-3.

69. Tice AD, Hoaglund PA, Shoultz DA. Risk factors and treatment outcomes in osteomyelitis. The Journal of antimicrobial chemotherapy. 2003 May;51(5):1261-8.

70. Silverman JA, Mortin LI, VanPraagh ADG, Li T, Alder J. Inhibition of daptomycin by pulmonary surfactant: In vitro modeling and clinical impact. Journal of Infectious Diseases. 2005;191(12):2149-52. 
71. Henken S, Bohling J, Martens-Lobenhoffer J, Paton JC, Ogunniyi AD, Briles DE, et al. Efficacy profiles of daptomycin for treatment of invasive and noninvasive pulmonary infections with Streptococcus pneumoniae. Antimicrob Agents Chemother. 2010 Feb;54(2):707-17.

72. Freire AT, Melnyk V, Kim MJ, Datsenko O, Dzyublik $\mathrm{O}$, Glumcher F, et al. Comparison of tigecycline with imipenem/cilastatin for the treatment of hospital-acquired pneumonia. Diagn Microbiol Infect Dis. 2010 Oct;68(2):140-51.

73. Synercid [package insert]. Bristol, TN: Monarch Pharmaceuticals, Inc and Greenville, NC: DSM Pharmaceuticals, Inc.; 2003.

74. American Thoracic Society, Infectious Diseases Society of America. Guidelines for the management of adults with hospital-acquired, ventilator-associated, and healthcare-associated pneumonia. American journal of respiratory and critical care medicine. 2005 Feb 15; 171(4):388-416.

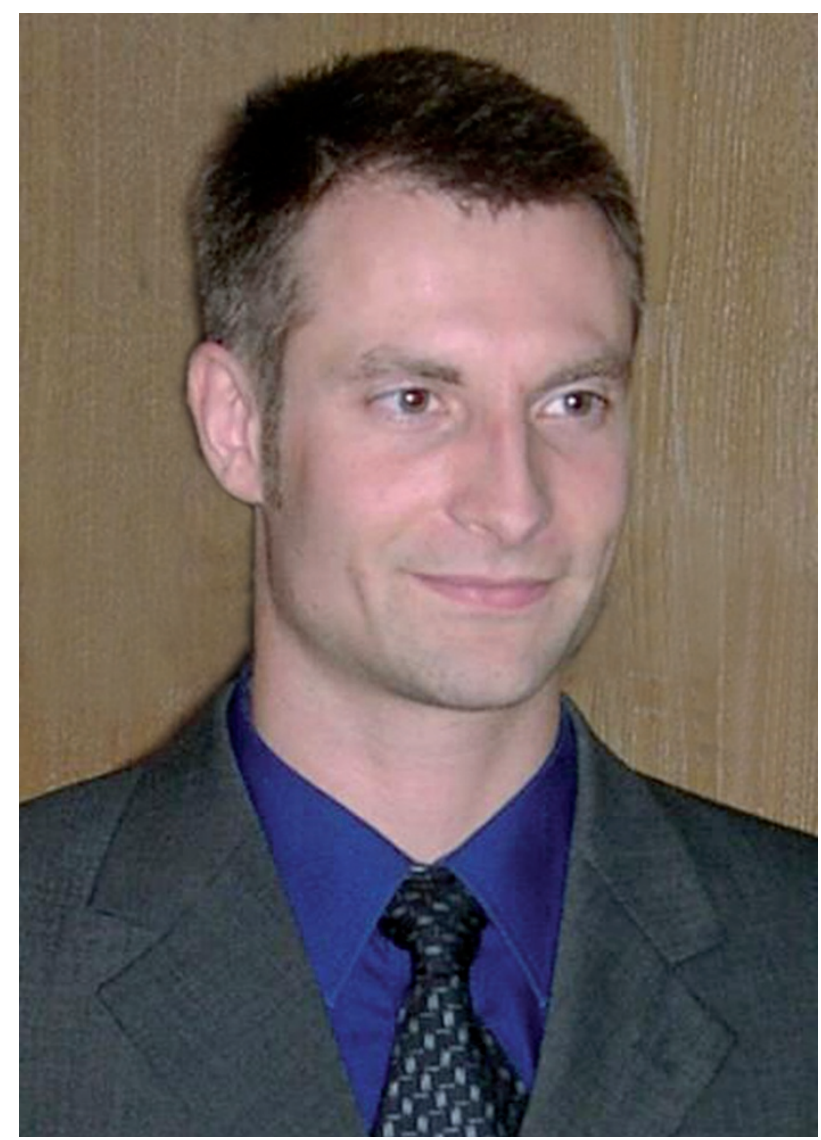

Mathias W. Pletz
75. Fagon JY, Patrick H, Haas DW, Torres A, Gibert C, Cheadle WG, et al. Treatment of Gram-positive nosocomial pneumonia. Prospective randomized comparison of quinupristin/dalfopristin versus vancomycin. Nosocomial Pneumonia Group. American journal of respiratory and critical care medicine. 2000 Mar;161(3 Pt 1):753-62.

Received: November 8, 2010 / Accepted: November 10, 2010

Address for correspondence:

Priv.-Doz. Dr. med. Mathias W. R. Pletz

Department of Pulmonary Medicine

Hannover Medical School

Carl-Neuberg-Str. 1

30625 Hannover

Germany

Phone: +49 (0) 5115323661

Fax: $\quad+49(0) 5115323353$

E-mail: pletz.mathias@mh-hannover.de 